\title{
An epidemiological study to find out the prevalence of RTI/STI and various factors associated with it among ever married women of reproductive age group in an urban slum community of Mumbai
}

\author{
Dr. Mangala M.Bote ${ }^{1}$, Dr.Shenoy A.G. ${ }^{2}$ \\ ${ }^{1}$ (Department of Community Medicine, Topiwala National Medical College, Mumbai, India) ${ }^{2}$ (Department of $e$, \\ Topiwala National Medical College, Mumbai, India)
}

\begin{abstract}
Background and objectives : Reproductive tract infection presents a huge burden of disease and adversely impacts reproductive health. A broad based study conducted in different part of the country revealed a prevalence of reproductive tract infections varying from 19 to $71 \%$. Marked variations have been found in terms of pattern and level of morbidity. The present study was undertaken with the following Objectives:

[1] To assess the prevalence of various reproductive tract infections among ever-married women aged 15 49 years based on laboratory diagnosis.

[2] To understand the influence of various factors on reproductive tract infections in women.

Material and methods: A Community based epidemiological study was undertaken over a period of 6 months from September 2007 to February 2008 in an urban slum, field practice area of Urban Health Centre (UHC), Total 500 ever married women of reproductive age group (15-49 years), residing in study area for more than 1 year, were selected by systematic sampling technique. Information was collected on preformed, pre tested interview schedule by investigator. At the end of the interviews, each woman was given an appointment card to visit at the clinic (Urban Health Centre) were Per speculum examination was carried out and Samples (vaginal and cervical swab) were collected for laboratory investigation of RTI/STI Result: $50 \%$ of women in the study reported one or more RTI related symptoms, the various symptoms reported by women were Vaginal discharge (44.2\%) Lower abdominal pain (13.6\%) Lesion over genital area (1.0\%) Inguinal swelling (0.8). Total 466 women had undergone gynaecological examination and laboratory investigations. The prevalence of women with at least one RTI, based on laboratory diagnosis, was found to be $67.81 \%$ (316/466). The total number of positive tests being 505. Thus, the number of RTIs per woman was 1.59 (505/316). On Logistic regression analysis, Among different variables, prevalence of RTI was influenced by gravida status, place of delivery, IUD use and with history of RTI/STI in last three months.
\end{abstract}

Keywords: Reproductive tract infection, sexually transmitted infection, Urban

\section{INTRODUCTION}

Reproductive health is crucial part of general health, yet many of the world's people do not have good reproductive health. Some have little or no control over their sexual lives and childbearing, others engage in behaviour that puts both them their partners at risk, while yet others simply do not have access to the right kind of information and services. Many girls and women are socially, politically and economically disadvantaged, have fewer educational opportunities and consequently have limited choices about their lives, their health and their fertility. Knowledge of the extent of reproductive ill health worldwide is far from complete, but estimate indicate that there are high rates of preventable conditions and avoidable suffering that often have devastating effect on individuals and families ${ }^{(1)}$

Reproductive and sexual ill-health (maternal and perinatal mortality and morbidity, cancers, sexually transmitted infections and HIV/AIDS) account for nearly $20 \%$ of the global burden of ill-health for women and some $14 \%$ for men. ${ }^{(2)}$

Reproductive tract infection presents a huge burden of disease and adversely impacts reproductive health of people. These infections cause suffering for both women and men around the world, but their consequences are far more devastating and widespread among women than among men. ${ }^{(3)}$

A broad based study conducted in different part of the country revealed a prevalence of reproductive tract infections varying from 19 to $71 \%$. Marked variation has been found across all these studies in terms of pattern and level of morbidity which means that no single set of estimates for RTIs, could apply in such a large and diverse country as India. Hence, the prevalence rates of RTIs for a particular geographical area need to be assessed so as to help the health administrator in providing better services for their treatment and control. ${ }^{(4)}$

A variety of factors that put women at risk of reproductive tract infection as well as consequences for women arising from such morbidity, such as socio- economic, demographic, sexual, medical, behavioural 
practices, personal hygiene behaviour have not been adequately explored in India. Concerted efforts are needed to provide useful information to health planners and policymakers so that appropriate strategies can be designed to bring about an improvement in reproductive health of women ${ }^{(5)}$

The present study was undertaken with the following Objectives:

[1] To assess the prevalence of various reproductive tract infections among ever-married women aged 15-49 years based on laboratory diagnosis.

[2] To understand the influence of various factors on reproductive tract infections in women.

\section{MATERIAL AND METHODS}

A Community based epidemiological study was undertaken over a period of 6 months from September 2007 to February 2008 in an urban slum, field practice area of Urban Health Centre (UHC), under Department of Preventive and Social Medicine, T.N. Medical College, Mumbai. Taking 46\% prevalence of reproductive health problem among urban women (NFHS-II) sample size was calculated by using formula, Sample Size $(n)=4 \mathrm{pq} / \mathrm{L}^{2}(\mathrm{~L}=10 \%$ allowable error of ' $\mathrm{p}$ ').

Total 500 ever married women of reproductive age group (15-49 years), residing in study area for more than 1 year, and who had not undergone hysterectomy, were selected by systematic sampling technique. Information was collected regarding socio-economic characteristics, marital history, personal hygiene behaviour, obstetric and contraceptive practices, sexual practices and behaviour, health seeking behaviour, past and present clinical symptoms of reproductive tract, husband's past and present history of STD and high risk behaviour, on preformed, pre tested interview schedule by investigator. Based on responses to the questions regarding present complaints related to RTIs; the women were labeled as symptomatic or asymptomatic. At the end of the interviews, each woman was given an appointment card to visit at the clinic (Urban Health Centre)

Per speculum examination was carried out and Samples were collected for laboratory investigation at UHC Endocervical swab: gonococcal infection (Gram staining) Vaginal swab:

$$
\begin{array}{lllll}
\text { 1. For trichomoniasis and } & \text { bacterial } & \text { vaginosis } & \text { (saline } & \text { wet } \begin{array}{r}
\text { mount) } \\
\text { 2. }
\end{array} \\
\text { For } & \text { candidiasis } & & (\mathrm{KOH} & \text { wet }
\end{array}
$$

3. Vaginal $\mathrm{pH}$ was measured with a $\mathrm{pH}$ strip indicator

-Blood investigations: RPR (syphilis)

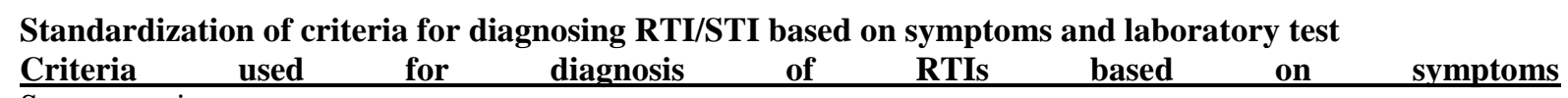
$\underline{\text { Symptomatic }}$

1. Vaginal discharge - complaints like profuse, foul smelling discharge, pain in abdomen, itching in vulval region, and burning micturation.

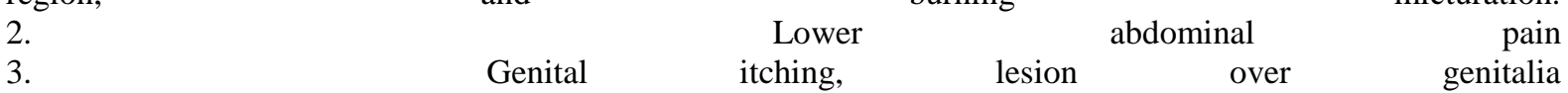

4. Inguinal Swelling

Asymptomatic: Without symptoms of illness related to RTIs/STIs

Criteria used for laboratory diagnosis

Reproductive tract infections - Diagnostic criteria

Gonorrhea- Identification of Gm -ve intracellular diplococci in Gram stained cervical smear

Non gonococcal cervicitis- >30 PMNs/hpf in Gram stained cervical smear

Trichomonas vaginitis- $\geq 1$ actively moving trichomonad (saline wet preparation), $\mathrm{pH}>5$

Bacterial vaginosis- Presence of "Clue" cells (saline wet preparation), Vaginal $\mathrm{Ph}>5$

Candidiasis- Presence of Pseudohyphae and budding yeast cells (KOH wet preparation) and vaginal $\mathrm{Ph}<5$

Syphilis- Nontreponemal test - VDRL

Diagnosing Trichomonas infection by wet mount preparation is approximately 60-98.2\% sensitive compared to trichomonas culture. ${ }^{6,7}$ The sensitivity of using Clue cells as diagnostic criteria for bacterial vaginosis is $80-98 \%$ when compared with more elaborative criteria for determining bacterial vaginosis. ${ }^{8}$

Detection of intracellular gram-negative diplococci in endocervical mucus is quite specific but $<=50 \%$ sensitive for gonorrhoea. The presence of $>=20$ polymorph nuclear cells per 1000 microscopic field within strands of cervical mucus not contaminated by vaginal squamous epithelial cells or vaginal bacteria indicate endocervicitis ${ }^{9}$ 
Operational Definitions:

Any one RTI: This includes gonococcal, trichomoniasis, bacterial vaginosis and candidiasis. Any one STI: This includes gonococcal and trichomoniasis.

\section{Statistical Analysis:}

To see the association between various factors and different RTIs, analysis was performed separately for reproductive tract infection (RTI) and sexually transmitted infection (STI) using software SPSS 15 for Microsoft windows. Laboratory diagnosis was used as criteria for analysis.

The bi-variate analysis, does not take into account the influence of background variables on prevalence of RTI/STIs independently. Also it may be possible that there may be confounding effect of each of background variable upon prevalence of RTI/STI variable, and thus a multivariate analysis has been carried out.

The dependant variable was dichotomized as the presence or absence of RTI/STI. The independent variable selected for the analysis fall into three main groups. The first group represent socio-demographic factors, the second group is obstetric and contraceptive practices and third group represents sexual behavior and practices of women.

In this analysis, odds ratio and associated $\mathrm{p}$ values were calculated for dependant and individual background variables. All variables are categorical in nature and from each variable, first category was selected as the reference category.

Ethics committee approval: This study was approved by the institute's research and ethical committees and informed consent was obtained from the respondents.

\section{RESULTS}

Proportion of respondents in five-year age groups increases from 3\% in the age group 15-19 years to $27 \%$ in the age group 25-29 years and then fall steadily to $4.4 \%$ in the age group $45-49$ years.. $76.4 \%$ respondents were Muslim, 20.2\% were Hindu and $3.4 \%$ were others. $94 \%$ of respondents were currently married and 5.8\% were single which includes widowed, divorced and separated. Maximum respondents were having Nuclear family (74.6\%) followed by joint family (23\%) and (2.4\%) 3 generation family. Percentage of literates in present study is $60 \%$, which is less than that of Mumbai slum area(66.4\%) and in Mumbai total is 75.8\% (NFHS II Maharashtra). $88 \%$ of women reported that they are not working aside from doing their own housework. $42.6 \%$ of women were from lower socioeconomic status (class IV \&V).

$50 \%$ of women in the study reported one or more RTI related symptoms, the various symptoms reported by women are summarised in TABLE 1 . More than one diagnosis has been given to some women, 250 $(50 \%)$ women were diagnosed to have at least one RTI , Total RTI symptoms reported -298 . Number of RTI per women $=1.19(298 / 250)$

TABLE. 1 Reproductive tract infections by syndromic approach, based on symptoms $(\mathrm{N}=\mathbf{5 0 0})$

\begin{tabular}{|c|c|c|}
\hline Symptoms & $\begin{array}{l}\text { Number } \\
\text { symptoms }\end{array}$ & f Percentage \\
\hline Vaginal discharge & 221 & 44.2 \\
\hline Lesion over genital area & 5 & 1.0 \\
\hline Lower abdominal pain & 68 & 13.6 \\
\hline Inguinal swelling & 4 & 0.8 \\
\hline Total (Reported RTI symptoms) & 298 & $59.6 \%$ \\
\hline No symptoms & 250 & $50 \%$ \\
\hline \multicolumn{3}{|l|}{ Other diagnosis } \\
\hline Menstrual irregularity & 36 & 7.2 \\
\hline Primary infertility & 4 & 0.8 \\
\hline Secondary infertility & 7 & 1.4 \\
\hline
\end{tabular}

Only 466 women had undergone gynecological examination and laboratory investigations. The various infections diagnosed in women are summarized in TABLE 2. 
TABLE 2. RTIs/STIs by laboratory investigation $(N=466)$

\begin{tabular}{|l|l|l|}
\hline RTI/STI & $\begin{array}{l}\text { No. of women } \\
\text { testing positive }\end{array}$ & percentage \\
\hline GC & 33 & 7.1 \\
\hline NGC & 169 & 36.3 \\
\hline TV & 63 & 13.5 \\
\hline BV & 65 & 13.9 \\
\hline Candidiasis & 175 & 37.6 \\
\hline Syphilis $(\mathbf{N}=\mathbf{4 0 7})$ & 0 & 0 \\
\hline HIV $(\mathbf{N}=\mathbf{4 0 7})$ & 0 & 0 \\
\hline $\begin{array}{l}\text { Total } \\
\text { RTIs present) }\end{array}$ & 505 & \\
\hline RTIs absent & 150 & 32.19 \\
\hline
\end{tabular}

The prevalence of women with at least one RTI, based on laboratory diagnosis, was found to be $\underline{67.81 \%}$

$(316 / 466)$.

The total number of positive tests being 505. Thus, the number of RTIs per woman was $\underline{1.59}(505 / 316)$.

On Logistic regression analysis, among different variables, prevalence of RTI was influenced by gravida status; place of delivery, IUD use and with history of RTI/STI in last three months. These are summarized in TABLE 3

TABLE 3. Logistic regression of reproductive tract infection by background characteristics of women

\begin{tabular}{|c|c|c|}
\hline \multicolumn{3}{|c|}{ women } \\
\hline \multirow{2}{*}{ Variables } & \multicolumn{2}{|l|}{ Any one RTI } \\
\hline & Sig. & Odds ratio \\
\hline Socio-demographic & \multirow[b]{2}{*}{0.568} & \multirow[b]{2}{*}{0.853} \\
\hline $\begin{array}{l}\text { Age in years } \\
>=35 \text { years }(r) \\
<35 \text { Years }\end{array}$ & & \\
\hline \begin{tabular}{|l|} 
Education \\
Illiterate (r) \\
literate \\
\end{tabular} & 0.948 & 0.983 \\
\hline $\begin{array}{l}\text { Occupation (Self) } \\
\text { Not working(r) } \\
\text { Working } \\
\end{array}$ & 0.345 & 1.453 \\
\hline \begin{tabular}{|l} 
Husband's occupation \\
Permanent place of work(r) \\
Not working \\
No permanent place of work \\
\end{tabular} & $\begin{array}{l}0.190 \\
0.649 \\
0.071\end{array}$ & $\begin{array}{l}1.446 \\
1.608 \\
\end{array}$ \\
\hline \multicolumn{3}{|l|}{ Obstetric and contraceptive practices } \\
\hline \begin{tabular}{|l} 
Gravida Status \\
$\quad>2$ gravid status(r) \\
$<=2$ Gravida status \\
\end{tabular} & 0.001 & 2.525 \\
\hline \begin{tabular}{|l} 
Place of delivery \\
Hospital(r) \\
Home \\
\end{tabular} & 0.058 & 2.842 \\
\hline \begin{tabular}{|r|} 
Delivery conducted by \\
Skilled attendant ${ }^{\circledR}$ \\
Unskilled attendant \\
\end{tabular} & 0.603 & 0.695 \\
\hline \begin{tabular}{|l|} 
History of abortion \\
No(r) \\
Yes \\
\end{tabular} & 0.649 & 0.893 \\
\hline \begin{tabular}{|l} 
Contraceptive use \\
Not using(r) \\
Using \\
\end{tabular} & 0.743 & 1.092 \\
\hline \begin{tabular}{|l|} 
IUD use \\
Not using(r) \\
Using
\end{tabular} & 0.015 & 2.870 \\
\hline \multicolumn{3}{|l|}{ Sexual behaviour } \\
\hline $\begin{array}{l}\text { Age at first sexual intercourse } \\
\quad>=21 \text { years }(r) \\
<21 \text { years }\end{array}$ & 0.318 & 1.327 \\
\hline \begin{tabular}{|l|} 
Weekly Frequency of sexual intercourse \\
Abstinence(r)
\end{tabular} & 0.138 & \\
\hline
\end{tabular}




\begin{tabular}{|c|c|c|}
\hline $\begin{array}{l}1-2 \\
>2\end{array}$ & $\begin{array}{l}0.347 \\
0.100 \\
\end{array}$ & $\begin{array}{l}1.654 \\
2.532 \\
\end{array}$ \\
\hline $\begin{array}{l}\text { Sexual practice } \\
\text { Vaginal(r) } \\
\text { Vaginal/anal/oral }\end{array}$ & 0.824 & 1.147 \\
\hline \begin{tabular}{|l} 
Past history of RTI/STI \\
No(r) \\
Yes \\
\end{tabular} & 0.000 & 2.961 \\
\hline $\begin{array}{l}\text { Husband's stay } \\
\text { Away(r) } \\
\text { Occasionally away } \\
\text { Together }\end{array}$ & $\begin{array}{ll}0.312 & \\
0.129 & \\
& 0.231 \\
\end{array}$ & \begin{tabular}{|l|}
2.613 \\
1.869 \\
\end{tabular} \\
\hline $\begin{array}{l}\text { Husband's STI at present } \\
\text { No(r) } \\
\text { Yes }\end{array}$ & 0.246 & 1.545 \\
\hline $\begin{array}{l}\text { Husbands STI in last three months } \\
\text { No(r) } \\
\text { Yes }\end{array}$ & 0.777 & 0.858 \\
\hline $\begin{array}{l}\text { Husband's high risk behaviour } \\
\text { No(r) } \\
\text { Yes }\end{array}$ & 0.613 & 228.723 \\
\hline Constant & 0.386 & 108.188 \\
\hline
\end{tabular}

The Prevalence of STI was influenced by type of husband's occupation, use of IUD, weekly frequency of sexual intercourse, and history of husband's having STI related symptoms reported by women. These factors are summarised in TABLE 4.

TABLE 4. Logistic regression of sexually transmitted infection by background characteristics

\begin{tabular}{|c|c|c|}
\hline \multirow[b]{2}{*}{ Variables } & \multicolumn{2}{|c|}{ Any one STI } \\
\hline & Sig. & OR \\
\hline Socio-demographic & \multirow[b]{2}{*}{0.257} & \multirow[b]{2}{*}{1.355} \\
\hline $\begin{array}{l}\text { Age in years } \\
>=35 \text { years }(\mathrm{r}) \\
<35 \text { Years }\end{array}$ & & \\
\hline $\begin{array}{l}\text { Education } \\
\quad \text { illiterate (r) } \\
\quad \text { literate }\end{array}$ & 0.228 & 1.349 \\
\hline $\begin{array}{l}\text { Occupation (Self) } \\
\text { Not working(r) } \\
\text { Working }\end{array}$ & 0.870 & 0.943 \\
\hline $\begin{array}{l}\text { Husband's occupation } \\
\text { Permanent place of work(r) } \\
\text { Not working } \\
\text { No permanent place of work }\end{array}$ & $\begin{array}{l}0.098 \\
0.337 \\
\mathbf{0 . 0 4 0}\end{array}$ & $\begin{array}{l}1.990 \\
1.606 \\
\end{array}$ \\
\hline Obstetric and contraceptive practices & & \\
\hline $\begin{array}{l}\text { Gravida Status } \\
>2 \text { gravid status(r) } \\
<=2 \text { Gravida status }\end{array}$ & 0.183 & 1.391 \\
\hline $\begin{array}{l}\text { Place of delivery } \\
\text { Hospital(r) } \\
\text { Home } \\
\end{array}$ & 0.250 & 1.636 \\
\hline $\begin{array}{r}\text { Delivery conducted by } \\
\text { Skilled attendant }(\mathrm{r}) \\
\text { Unskilled attendant } \\
\end{array}$ & 0.843 & 1.114 \\
\hline $\begin{array}{l}\text { History of abortion } \\
\text { No(r) } \\
\text { Yes }\end{array}$ & 0.057 & 0.638 \\
\hline $\begin{array}{l}\text { Contraceptive use } \\
\text { Not using(r) } \\
\text { Using } \\
\end{array}$ & 0.364 & 1.265 \\
\hline $\begin{array}{l}\text { IUD use } \\
\text { Not using(r) } \\
\text { Using } \\
\end{array}$ & 0.004 & 2.875 \\
\hline Sexual behaviour related factors & & \\
\hline $\begin{array}{l}\text { Age at first sexual intercourse } \\
>=21 \text { years( }(\mathrm{r}) \\
<21 \text { years }\end{array}$ & 0.464 & 1.254 \\
\hline $\begin{array}{l}\text { Weekly Frequency of sexual intercourse } \\
\text { Abstinence(r) }\end{array}$ & .021 & 6.928 \\
\hline
\end{tabular}




\begin{tabular}{|c|c|c|}
\hline $\begin{array}{l}1-2 \\
>2\end{array}$ & .007 & 9.091 \\
\hline $\begin{array}{l}\text { Sexual practice } \\
\text { Vaginal(r) } \\
\text { Vaginal/anal/oral }\end{array}$ & 0.824 & 0.889 \\
\hline $\begin{array}{l}\text { Past history of RTI/ST } \\
\text { No(r) } \\
\text { Yes }\end{array}$ & 0.257 & 1.288 \\
\hline $\begin{array}{l}\text { Husband's stay } \\
\text { Away(r) } \\
\text { Occasionally away } \\
\text { Together }\end{array}$ & $\begin{array}{l}0.505 \\
0.362 \\
0.785\end{array}$ & $\begin{array}{l}1.709 \\
1.150\end{array}$ \\
\hline $\begin{array}{l}\text { Husband's STI at prese } \\
\text { No(r) } \\
\text { Yes }\end{array}$ & 0.013 & 2.353 \\
\hline $\begin{array}{l}\text { Husbands STI in last t } \\
\text { No(r) } \\
\text { Yes }\end{array}$ & 0.719 & 1.201 \\
\hline $\begin{array}{l}\text { Husband's high risk be } \\
\text { No(r) } \\
\text { Yes }\end{array}$ & 0.533 & 707.889 \\
\hline Constant & 0.503 & 34.622 \\
\hline
\end{tabular}

\section{Discussion}

In the present community based study, the prevalence of reported morbidity of RTI/STIs was $50 \%$. Prevalence of reported morbidities range from $65 \%$ to $84 \%$ in four community based studies conducted in urban slum of Mumbai, Baroda and West Bengal ${ }^{(4)}$. The prevalence of RTIs in the present study is on lower side when compared with the above-mentioned studies.

The prevalence of women with at least one RTI, based on laboratory diagnosis, was found to be $67.81 \%$ (316/466). GC was detected in $33(7.1 \%)$ women, NGC in $169(36.3 \%)$ women. The prevalence of NGC is high in our study. No woman was seropositive for syphilis. A Study done by Parikh et al ${ }^{(10)}$ in Bombay slum, showed that the most commonly observed infection was chlamydia (14\%), trichomoniasis (10\%), but other STDs, such as gonorrhoea and syphilis (VDRL) were rarely observed $1.5 \%$ and $0.3 \%$ of all women respectively.

Logistic regression analysis shows that, the odds of having STI among women with husbands having no permanent place of occupation were about 1.60 times higher. This is relevant, in view of migration or travel in search of occupation playing a role in the spread of STI. This finding is supported by study conducted by Jasmin Helen Prasad ${ }^{11}$ in South India and in a study done by J.Bogaerts et $\mathrm{al}^{12}$ among women in Dhaka. Among obstetric and contraceptive practices, odds of having STI among women who were using IUD were 2.87 times higher than among those not using IUD. This may be due to unhygienic condition during IUD insertion, insertion of IUD in women who harbour pathogens, IUD string facilitate access to the upper genital tract for bacteria ${ }^{13}$ A study done by Wasserheit J.N. ${ }^{14}$ in rural Bangladesh showed that IUD users 4 times more likely to report abnormal vaginal discharge. Among sexual behaviour and practices, having sex $>$ twice/week had higher odds (9.09 times) of having STI, this can be explained by the fact that, increased frequency can lead to atypical changes in the lower reproductive tract like abrasions which increases the risk of contracting STI, evidence in favour of spermatozoa acting as vector is much stronger and also female organic contractions may be responsible for drawing both sperm and organisms through the cervical barrier. Jasmine Helen Prasad ${ }^{11}$ in South India studied this relationship, but the distribution was statistically not significant. Women whose husbands were symptomatic, had higher odds (2.35) of having STI. This finding is supported by the study conducted in Goa by Patel V. et al. ${ }^{15}$

Prevalence of RTI was influenced by gravida status, place of delivery, IUD use and past history of RTI/STI. Women with gravida status $<=2$ had higher odds (2.52) of having RTI than that of women with $>2$ gravida status. The odds of having RTI among women who had inserted IUD were 2.87 times higher than those not using IUD. Women with history of RTI/STI in last three months were more likely to get infected with RTI(2.96).This probably shows that the women who were symptomatic in last three months were most likely to have suffered from endogenous infection because endogenous infection may have relapsing and remitting course in some women.

\section{Conclusion}

The most important conclusion of this study was high prevalence of RTI/STIs which are associated with adverse outcome and this should be considered during antenatal care. More than half of the women who were asymptomatic were found to be positive on laboratory report. Thus it is needed to find out alternative ways like screening of women who come to general OPD for other reason, women attending health clinics for family planning and antenatal services. Our findings have significant implications for family planning service 
provision. Selective screening of women requesting an IUD and women who have yet to attain desired family size would be one approach to rationing costly case finding. STIs were more among women whose husband were symptomatic. Involvement of the males in the treatment and prevention of RTIs will bring about better results in treatment outcome as well as prevent the recurrence of the infection.

\section{Acknowledgements}

We thank the research and ethical committees of Topiwal National Medical College for approving our study.

\section{References}

[1] The Global Burden of Reproductive ill health PROGRESS newsletter in Human Reproduction Research, PROGRESS,(42):2,1997

[2] Reproductive health strategy, to accelerate progress towards the attainment of international development goals and targets, (World Health Organisation 2004, Geneva):14-19

[3] Prevention and control of sexually transmitted infections: draft global strategy, (World Health Organisation, fifty-ninth World Health Assembly,A59/11,18 May 2006):10

[4] Latha K, Kanai, S.J., Maitra, bhatt G.B., Prevalence of clinically detectable gynecological morbidity in India-result of four community based studies, The journal of family welfare ;43(4)1997, 8-16.

[5] Bhatia J.C., and Cleland J. "Self reported symptoms of gynecological morbidity and their treatment in south India", Studies in family Planning, 26(4),1995,203-216

[6] J.N.Krieger; et al, Diagnosis of Trichomoniasis: Comparision of conventional Met-mount examination with cytologic studies, culture and Monoclonal antibody staining of direct specimens, Journal of American Medical Association, 259(8),1998,1223-1227

[7] Angelika stary, Angelika Kuchinka-koch and Lilianna Teodorowicz, Detection of Trichomonas vaginalis on Modified Columbia Agar in thr Routine Laboratory, Journal of Clinical Microbiology, 40(9), 2002, 3277-3280.

[8] Thomason J.L et al, Statistical evaluation of diagnostic criteria for bacterial vaginosis, Am J Obstet Gynecol, 162(1),1990,155-160.

[9] King K. Holmes, Sexually transmitted diseases: Overview and Clinical approach, Harrison's Principles of internal Medicine , (Newyorkr: McGraw-Hill Professional6th edition):768

[10] Dr. Indumati Parikh, Dr. Vijayalaxmi Tasker, Dr.Neela Dharap. Dr.Veen Mulgaonker, Gynecological morbidity among women in Bombay slum,Streehitkarni, Mumbai, India 1996, Unpublished paper, IIPS.

[11] Jasmin Helen Prasad et al, Reproductive Tract Infections among Young Married Women in Tamil Nadu, India, International Family planning perspective, 31(2), 2005,73-82.

[12] J.Bogaerts, et al, Sexually transmitted infections among married women in Dhaka, Bangladesh, Sexually Transmitted Infections, 77(2), 2001,114-119

[13] Richard L.Sweet, Ronald S. Gibbs, Chlamydial Infection in Infectious Disease of Female Genital Tract, (Lippicott Williams and Wilkins publisher, 4th edition 2002), 69.

[14] Wasserheit J.N., Haris J.R., Chakraborty J., Kay B..A., Mason K.J., Reproductive tract infections in family planning population in rural Bangladesh, Studies in Family planning ,20(2), 1989,69-80.

[15] V.Patel et al.,The burden and determinants of reproductive tract infections in India: a population based study of women in Goa India, Sexually Transmitted Infections,82(3),2006, 243-249. 